\title{
The Illustration of Physical Activity and the Elderly Physical Fitness Level
}

\author{
Bintang Kusuma Wardhana*, Muhammad Hamid Anwar \\ Magister of Sport Science Program \\ Yogyakarta State University \\ Kabupaten Sleman Daerah Istimewa Yogyakarta, Indonesia \\ *pps@uny.ac.id
}

\begin{abstract}
This research was aimed at knowing: (1) the physical activity of the elderly in Wredha Budhi Dharma Senior Residence, (2) the physical fitness of the elderly in Wredha Budhi Dharma Senior Residence, and (3) any factor that influences the physical activity and physical fitness level of elderly in Umbulharjo Wredha Budhi Dharma Senior Residence, Yogyakarta. The method used in this research was a combination of qualitative and quantitative method (mixed-method). A quantitative method was used to know the depiction of physical fitness of elderly through test and measurement (Fitness of Older Adult). While the qualitative method was used to know the physical activities with various influencing factors by using observation and interview. This research was conducted in Umbulharjo Wredha Budhi Dharma Senior Residence, Yogyakarta. The data were analysed by using a descriptive analysis to describe and to explore the meaning of data from each of research aspect. The result of this research, related to the physical fitness level of the elderly in Wredha Budhi Dharma Senior Residence, shows that three people, or about $14.28 \%$, were in a high category according to the body vitality result, 16 people, or about $76.20 \%$, were classified in the medium category, and 2 people, or about $9.52 \%$, got low body vitality result. The research result also shows that elderlies with good physical fitness level are supported by physical activities. Furthermore the supportive factors causing the elderly to be physically active are the background of location in Wredha Budhi Dharma Senior Residence, gender, kind of activity, and social environment. After being deeply researched, it was found that elderlies living in Wredha Budhi Dharma Senior Residence are the ones who decide to live there by themselves and they tend to be more active and obtain high result of physical fitness level and the opposition does too.
\end{abstract}

Keywords: elderly, physical activity, physical fitness

\section{INTRODUCTION}

The number of elderly in Indonesia is increasing. It is proven by the data from the Coordinating Minister for People Welfare on 2016 that the number of elderly has reached 19 million lives and increased into 23.9 million lives in 2010 [1]. Even the United States Census Bureau estimates that Indonesia will experience the greatest increase of elderly population in the whole world in 1990 to 2025, which is about 414\%. One of the factors of elderly life expectation is the social or surrounding environment [2]. Another research says that in order for the elderly to survive longer, the people near them or those who are close to them have to organize the life management for the elderly [3].

Life quality of a person is strongly related to physical activities [4]. In addition, another research says that physical activities have strong influence toward life satisfaction and is positive for life [5]. Some other researches also say that physical activities are important for children [6], physical activities are important for children with asthma [7], physical activities are important for the elderly [8]. By doing more physical activities regularly, the health and welfare of the elderly will turn better [9]. Recently, it is also said that physical activities can help not only for healthy aging but also help to prevent chronic illness [10].

Low level of physical activities will have an impact on physical fitness, which is related to health [11]. Previous research shows the positive effect of physical activities toward life satisfaction [12], but other findings say that physical fitness has no relation to high level of life satisfaction [13]. The elderly are very vulnerable to diseases because they are at high risk of death due to infection or other complications [14]. For that reason, this research is expected to provide the answers regarding to what factors that may influence the elderly physical activities and then the level of their physical fitness can be seen.

\section{METHOD}

This research uses mix-method, in which the researchers conduct the research by using the combination of quantitative and qualitative methods. Mix-method is used because this research produces two kinds of data, quantitative and qualitative.

The mix-method used in this research is the concurrent mix-method, which is the procedure in which the researchers bring together or combine quantitative and qualitative data in order to acquire comprehensive analysis of the research problems [15]

The populations in this research are elderly in Wredha Budhi Dharma nursing home. The technique used to collect sample in this research is purposive sampling. As for the considerations set are as follow:

- Elderly who are 60 years old and over, 
- 30 second chair stand test,

- Elderly who can still move, can at least stand up,

- Female,

- Male,

- Elderly who can still talk.

\section{RESEARCH INSTRUMENT}

The researchers adopt and combine two kinds of standard physical test instrument, they are Fitness of Older Adult measurement, Comparative Analysis of the Indicators of the Functional Fitness of the Elderly [16] that have 0.99 reliability, 0.94 validity and 0.95 objectivity and Physical Fitness Measurement for the Elderly [17].

\section{DATA ANALYSIS}

\section{QUANTITATIVE}

Data Collection

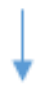

Data Analysis

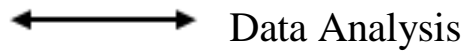

(Results of data that have been compared)

Fig. 1. Concurrent triangulation strategy [15].

\section{RESULTS}

\section{A. Qualitative Data Result}

The activities done by the elderly in Wredha Budhi Dharma nursing home are mostly given by the nursing home rather than doing their own individual activities. While conducting the observation, the researchers notice that there are no routine activities carried out by the elderly, they just sit in front of the nursing home and talk to other elderly friends.

Based on the observation and interview, based on the results of fitness test, the elderly who are in the nursing home on their own wishes have higher scores compared to the elderly who are in the nursing home because they are brought into the nursing home by their family.

By looking at the observation and interview data, the researchers notice that there is a 70 years old elderly who is still capable of doing routine activities or physical activities well.

Kinds of Fitness of Older Adult Test, Comparative Analysis of the Indicators of the Functional Fitness of the Elderly are as follow:

- 6 minute walk test,

- 2 minute step test,
- Arm curl test,

- Chair sit and reach,

- Back stretch,

- 8 up and go.

Kinds of Health Related Physical Fitness Measurement Test for the Elderly are as follow:

- 2,4 km Walk Test,

- Body Mass Index,

- Body Fat,

- Grip Strength Test.

Other than that, there is also a 70 years old elderly who is not fully capable of doing the activities well. From that we can already see that even with the same age, but the daily activities that they can do are different, the kinds of activities carried out regularly and repeatedly by the two elderly are different.

\section{B. Results of Quantitative Data}

Based on the results of 6 Minutes' Walk Test, there are 2 elderly or about $9.5 \%$ of the elderly whose results are in good category and the other 19 elderly or about $90.5 \%$ of the elderly who are in poor category.

Based on the results of 30 Second Chair Stand Test, there is one elderly or about $4.5 \%$ of the elderly whose result is in poor category and there are 21 elderly or about $95.5 \%$ of the elderly whose results are in good category.

Based on the results of Arm Curl Test, there are 4 elderly or about $23.5 \%$ of the elderly whose results are in poor category and there are 13 elderly or about $76.5 \%$ of the elderly whose results are in good category.

Based on the results of Chair Sit and Reach Test, there are 2 elderly or about $8.7 \%$ of the elderly whose results are in good category and there are 21 elderly or about $91.3 \%$ of the elderly whose results are in poor category.

Based on the result of Back Stretch Test, there are 10 elderly or about $55.6 \%$ of the elderly whose results are in poor category and there are 8 elderly or about $44.4 \%$ of the elderly whose results are in good category.

Based on the measurement of Body Mass Index, there are 10 elderly or about $43.5 \%$ of the elderly whose results are in normal category, there are 3 elderly or about $13 \%$ of the elderly whose results are above the normal category and there are 10 elderly or about $43,5 \%$ of the elderly whose results are below the normal category.

\section{DISCUSSION}

Low physical fitness of a person may be due to physical activities factors he or she carried out every day. Other researcher also explains that the level of physical fitness may results in greater health [18], for that reason, the physical 


\section{CONCLUSIONS}

Based on the results of research conducted by researchers, then the following conclusions can be drawn as follows:

- The physical fitness test results show that there are 3 people who get high physical fitness results or around $14.28 \%, 16$ people who get moderate physical fitness results or around $76.20 \%$, and 2 people who get low physical fitness results. or around 9.52. Of the few physical fitness test items the lowest results are from the element of flexibility or the Chair Sit and Reach Test and Back Scratch Test, both of these tests get an average of less categorized test results.

- From the results of physical activity, there were several respondents involved in this study. The average physical activity undertaken was elderly gymnastics, making handicrafts, Christian spiritual guidance and Islamic spiritual mentoring, singing, community service work (cleaning the rooms themselves), etc. The physical activities are some routine activities provided by the Wredha Budhi Dharma Orphanage, on the other hand there are also some elderly people who often do their own activities outside the activities provided by the orphanage, such as walking in the morning, sunbathing, pushing wheels, shopping at the mini market by foot, etc.

- Factors that influence physical activity and physical fitness test results include the background of the elderly can be at the Wredha Orphanage, type of activity, gender, and the influence of the social environment. The most highlighted factor is the background, it turns out that the background has an impact on the level of motivation of the elderly to do activities at the orphanage. Elderly who choose to stay at the Budhi Dharma Orphanage of their own will tend to be more active and the results of physical fitness tests also get a high category, while conversely the elderly who live at the Budha Dharma Orphanage are brought by their families to be passive and get physical fitness test results categorized as less so that physical activity is also lower. So that the elderly's background is one of the factors that influence the physical activities of the elderly at the Wredha Budhi Dharma Home and indirectly it will have an impact on their level of physical fitness and quality of life.

The conditions of the elderly in Wredha Budhi Dharma nursing home are very varied, but according to the results of interview with the nurse, there are more elderly who are healthy compared to those who aren't, the nurse even says that "out of the 58 elderly, there are 40s who are healthy". Based on the nurse's statement, we can see that most of the elderly in Wredha Budhi Dharma nursing home are healthy. Therefore, if most of the elderly in Wredha Budhi Dharma nursing home are healthy, they are supposed to be able to follow the activities given by the nursing home. In reality, based on the observation the researchers notice that there are only a few elderly who often follow the activities.

\section{REFERENCES}

[1] Nugraha, Lanjut Usia Indonesia, Kompasiana, Desember 2010

[2] M. Adinkrah, "Characteristics of elderly suicides in ghana," OMEGA Journal of Death and Dying, 2018.

[3] M.L. Shyu, H.C. Huang, M.J. Wu and H.J. Chang, "Development and validation of the self-awareness of falls in elderly scale among elderly inpatients," Clinical Nursing Research, vol. 27(1), pp. 105-120, 2017.

[4] A. Clifford, T.B. Rahardjo, S. Bandelow and E. Hogervorst, "A crosssectional study of physical activity and health-related quality of life in an elderly indonesian cohort," British Journal of Occupational Therapy, vol. 77(9), pp. 451-456, 2014 
[12] W. Bae, Y.I. Suh, J. Ryu and J. Heo, "Physical activity levels and wellbeing in older adults," Psychological Reports, vol. 120(2), pp. 192-205, 2017.

[13] K. Busing and C. West, "Determining the relationship between physical fitness, gender, and life satisfaction," SAGE Open, vol. 6(4), 2016.

[14] C. Crump, J. Sundquist, M.A. Winkleby and K. Sundquist, "Interactive effects of physical fitness and body mass index on risk of stroke: A national cohort study," International Journal of Stroke, vol. 11(6), pp. 683-694, 2016.

[15] W.J. Creswell, "Research design pendekatan kualitatif, kuantitatif, dan mixed," Yogyakarta: Pustaka Pelajar, 2013.

[16] C.J. Jones and R. Rikli, "Fitness of older adult. journal : division of kinesiology and health promotion," California State University, vol. 1(2), 2002.

[17] N. Kusmaedi, "Olahraga lansia," Bandung: CV. Bintang Warli Artika, 2008.

[18] P. Gísladóttir, M. Haga and H. Sigmundsson, "Physical fitness measures among adolescents with high and low motor competence," SAGE Open, vol. 3(3), 2013.

[19] C. Crump, J. Sundquist, M.A. Winkleby and K. Sundquist, "Interactive effects of physical fitness and body mass index on risk of stroke: A national cohort study," International Journal of Stroke, vol. 11(6), pp. 683-694, 2016. 